\title{
HUBUNGAN KECERDASAN EMOSIONAL DENGAN HASIL BELAJAR BIOLOGI PADA SISWA KELAS VII SMPN 21 BATAM
}

\section{THE CORRELATION BETWEEN EMOTIONAL INTELLIGENCE AND BIOLOGY LEARNING OUTCOMES AT CLASS VII SMPN 21 BATAM}

\author{
Yeri Novita $^{1}$, Fenny Agustina* ${ }^{2}$, Notowinarto Notowinarto ${ }^{3}$ \\ ${ }^{1,2,3}$ Program Studi Pendidikan Biologi, FKIP, Universitas Riau Kepulauan, Batam \\ *Koresponden: fennyagustina@gmail.com
}

\begin{abstract}
Abstrak
Penelitian ini bertujuan untuk mengetahui hubungan antara kecerdasan emosinal dengan hasil belajar siswa pada pembelajaran biologi. Penelitian dilaksanakan di SMPN 21 Batam, selama 5 (lima) bulan. Penelitian menggunakan metode survey korelasi dan populasi terjangkau adalah kelas VII6 dan VII7. Pengambilan sampel menggunakan teknik acak sederhana. Data hasil penelitian meliputi: Data hasil belajar siswa, yang diperoleh menggunakan tes hasil belajar dan data kecerdasan emosional siswa, diperoleh menggunakan angket siswa. Análisis data dilakukan secara deskriptif dan inferensial menggunakan teknik analisis varians (Anava). Hasil penelitian menunjukkan terbukti nyata ada hubungan antara kecerdasan emosional dengan hasil belajar siswa SMPN 21 Batam $\left(\mathrm{F}_{\text {hitung }} 1097,79>\mathrm{F}_{\text {table }} \alpha 5 \%\right.$ 1,82) dengan persamaan $\hat{\mathrm{Y}}=282.6-1.17 \mathrm{X}$, yang berarti bahwa regresi antara variabel bebas kecerdasan emosional siswa $(\mathrm{X})$ dengan variabel terikat nilai hasil belajar $(\mathrm{Y})$ adalah linier dan signifikan. Berarti setiap kenaikan satu skor kecerdasan emosional siswa (X) menyebabkan peningkatan nilai hasil belajar (Y) sebesar 1,17 pada konstanta 282,6. Nilai korelasi (r) sebesar 0,963 dan koefisien determinasi $\left(\mathrm{R}^{2}\right)$ sebesar 0,927 . Untuk selanjutnya dilakukan uji signifikansi koefisien kolerasi menggunakan Uji t terlihat bahwa $t_{\text {hitung }}(32.69)>$ dari $t_{\text {tabel }}(0.95 ; 84)$ 1.671. Artinya hasil pengujian menolak hipotesis nol (Ho). Disimpulkan bahwa terdapat hubungan antara kecerdasan emosional dengan hasil belajar siswa dalam pembelajaran biologi.
\end{abstract}

Kata Kunci: Kecerdasan emosional, Hasil belajar, Korelasi dan Anava

\begin{abstract}
This study aims to determine the correlation between emotional intelligence and students' learning outcomes on biology matter. This study was conducted at SMPN 21 Batam for five months. This study used correlation survey method and population was calass VII6 and VII7. Sample was taken by using using simple random technique. population surveys are affordable and VII7 VII6 class and sampling using simple random technique. Data result covered students' learning outcome which got from $t$ test learning and students' emotional intelligence data which gathered from questionnaire. Data analysis was descriptively and inferential of analysis techniques of variance (ANOVA). The results showed that there is a significant correlation between emotional intelligence and learning outcomes of students of SMPN 21 Batam (1097.79 F count $>$ F table 1,82 $\alpha$ 5\%) with the equation $Y=282.6-1: 17 \mathrm{X}$, which means that the regression between independent variables intelligence Emotional student $(X)$ and dependent variable values learning outcomes $(Y)$ is linear and significant. It means that every one score decretion of students' intelligence Emotional $(X)$ affected to students' learning outcomes decration $(Y)$ as 1,17 at constant 282,6. Correlation values ( $r$ ) of 0.963 and a coefficient of determination (R2) of 0.927. further test, coefficient significance correlation was done by using t-test shows that the t-count (32.69)> from t-table $(0.95 ; 84) 1,671$. This means that the test results reject the null hypothesis $(\mathrm{Ho})$. It is Concluded that there is correlation between emotional intelligence and learning outcomes of students on learning biology.
\end{abstract}

Key Words : Emotional intelligence, Learning outcomes, Correlation and Anova 


\section{PENDAHULUAN}

Dalam pendidikan formal, belajar menunjukkan adanya perubahan yang sifatnya positif sehingga pada tahap akhir akan didapat keterampilan, kecakapan dan pengetahuan baru. Hasil dari proses belajar tersebut tercermin dalam prestasi belajarnya. Namun dalam upaya meraih prestasi belajar yang memuaskan dibutuhkan proses belajar dalam jangka waktu tertentu (Irwanto,1997). Banyak pendapat menyatakan bahwa untuk meraih prestasi yang tinggi dalam belajar, seseorang harus memiliki Intelligence Quotient (IQ) yang tinggi, karena inteligensi merupakan bekal potensial yang akan memudahkan dalam belajar dan pada gilirannya akan menghasilkan hasil belajar yang optimal.

Kenyataannya, dalam proses belajar mengajar di sekolah sering ditemukan siswa yang tidak dapat meraih hasil belajar yang setara dengan kemampuan inteligensinya. Ada siswa yang mempunyai kemampuan inteligensi tinggi tetapi memperoleh hasil belajar yang relatif rendah, namun ada siswa yang walaupun kemampuan inteligensinya relatif rendah, dapat meraih hasil belajar yang relatif tinggi. Itu sebabnya taraf inteligensi bukan merupakan satu-satunya faktor yang menentukan keberhasilan seseorang, karena ada faktor lain yang mempengaruhi. Menurut Goleman (2000), kecerdasan intelektual (IQ) hanya menyumbang $20 \%$ bagi kesuksesan, sedangkan $80 \%$ adalah sumbangan faktor kekuatan-kekuatan lain, diantaranya adalah kecerdasan emosional atau Emotional Quotient (EQ) yakni kemampuan memotivasi diri sendiri, mengatasi frustasi, mengontrol desakan hati, mengatur suasana hati ( mood), berempati serta kemampuan bekerja sama. Hal ini menunjukan bahwa IQ atau rational intelligence yakni model pemahaman yang lazim juga perlu mengembangkan emotional intelligence juga dapat memperkirakan prestasi belajar seseorang.

Kecerdasan emosional dalam pendidikan, bagi sebagian orang memberikan definisi baru terhadap kata cerdas. Walaupun EQ merupakan hal yang relatif baru dibandingkan IQ, namun beberapa penelitian telah mengisyaratkan bahwa kecerdasan emosional tidak kalah penting dengan IQ. Kecerdasan emosional mencakup pengendalian diri, semangat, ketekunan serta kemampuan untuk memotivasi diri sendiri dan bertahan menghadapi frustasi, kesanggupan untuk mengendalikan dorongan hati dan emosi, tidak melebih-lebihkan kesenangan, mengatur suasana hati, tidak melumpuhkan kemampuan berpikir, kemampuan membaca perasaan terdalam orang 
lain (empati) dan berdoa, kemampuan memelihara hubungan dengan sebaik-baiknya, kemampuan untuk menyelesaikan konflik, serta kemampuan untuk memimpin. Lebih lanjut EQ mempunyai peran penting dalam menciptakan kemampuan dan keterampilan untuk produktif dan berhasil. Seiring dengan kemajuan kajian administrasi dan profesi yang mengakui pentingnya dimensi intelektual, emosional dan fisik dalam mendukung keberhasilan di dunia kerja. Khusus pada orang-orang yang murni hanya memiliki kecerdasan akademis tinggi, mereka cenderung memiliki rasa gelisah yang tidak beralasan, terlalu kritis, rewel, cenderung menarik diri, terkesan dingin dan cenderung sulit mengekspresikan kekesalan dan kemarahannya secara tepat. Hasil penelitian banyak terbukti bahwa kecerdasan emosional memiliki peran yang jauh lebih signifikan dibanding kecerdasan intelektual (IQ) yakni akan mengantarkan seseorang menuju puncak prestasi (Ahmad Rivai, 2007).

Penelitian bertujuan mengetahui apakah terdapat hubungan antara kecerdasan emosional dengan hasil belajar biologi pada siswa kelas VII SMP Negeri 21 Batam?. Dengan materi dibatasi pada skor EQ berdasarkan aspek kesadaran diri, pengendalian diri, motivasi diri, empati dan kerjasama.

\section{METODOLOGI}

Pelaksanaan penelitian ini dilakukan pada semester genap selama 5 (lima) bulan di SMP Negeri 21 Sagulung-Batam. Penelitian bersifat kuantitatif menggunakan metode survey kolerasi untuk memperoleh informasi variabel penelitian dan selanjutnya dianalisis hubungan antar variabel tersebut. Ada 2 (dua) variabel yaitu kecerdasan Emosional (X) sebagai variabel bebas dan hasil belajar Biologi siswa (Y) yang menjadi variabel terikat. Tingkat kecerdasan emosional siswa diperoleh dengan menggunakan angket yang disusun untuk tujuan penelitian ini serta hasil belajar sebagai variabel terikat menjadi fokus penelitian merupakan pencapaian siswa setelah mengikuti pembelajaran terhadap suatu kompetensi dasar yang telah ditetapkan dan dijabarkan dalam berbagai indikator penilaiannya. Populasi penelitian terjangkaunya adalah seluruh siswa kelas VII dan sampling dengan menggunakan teknik acak sederhana (simple random sampling).

Pengumpulan data berupa nilai tes hasil belajar Biologi dan nilai kecerdasan emosional siswa. Nilai hasil belajar siswa diperoleh menggunakan tes pilihan ganda, 
sedangkan nilai kecerdasan emosional diperoleh menggunakan angket siswa. Instrumen tes hasil belajar Biologi siswa kelas VII SMP disusun berdasarkan klasifikasi kognitif meliputi kemampuan untuk mengingat, memahami, menerapkan, menganalisis, mengevaluasi dan mencipta. Sedangkan tes hasil belajar disusun berdasarkan skala dikotomi, yaitu untuk setiap jawaban yang benar diberikan nilai satu, sedangkan untuk jawaban yang salah diberikan nilai nol. Nilai tes yang diperoleh siswa dari keseluruhan jawaban yang benar dibagi dengan keseluruhan jumlah soal yang dikalikan seratus.

Angket siswa yang digunakan untuk mengukur kecerdasan emosional disusun berdasarkan skala Likert 1-5 yaitu aspek kesadaran diri, pengendalian diri, motivasi, empati dan kerjasama. Kriteria Penskoran tanggapan siswa sebagai berikut: Skor $5=$ Jika siswa sangat setuju; Skor 4 = Jika siswa setuju; Skor $3=$ Jika siswa tidak memberikan tanggapan; Skor 2 = Jika siswa sangat tidak setuju; dan Skor 1 = Jika siswa tidak sangat setuju. Angket sebelum digunakan dikalibrasi untuk menganalisis validitas butir setiap soal yang dibuat dan tingkat reliabelitas angket secara keseluruhan. Validitas setiap butir, pernyataan angket dilakukan dengan uji korelasi product moment.

Sedangkan Reliability angket diuji dengan korelasi Alpha Cronbach pada taraf signifikasi 1 - 0,05. Data dianalisis menggunakan stastistik deskriptif inferensial yakni menyajikan data masing-masing variabel penelitian, meliputi ukuran gejala pusat, berupa rata-rata, median dan modus, serta ukuran penyebaran atau variabilitas data berupa rentang, variasi dan standar deviasi. Data deskriptif disajikan dalam bentuk tabel frekuensi dan divisualisasikan menggunakan grafik histogram. Kemudian sebelum melakukan uji inferensial, dilakukan uji prasyarat data, meliputi uji normalitas data dengan menggunakan Uji Liliefors dan uji homogenitas data menggunakan Uji Barlett. Untuk menguji hipotesis menggunakan korelasi product moment Pearson, Pengujian signifikasi koefisien kolerasi menggunakan uji t (t-test) dan hubungan fungsional antara dua variabel menggunakan regresi linear sederhana.

\section{PEMBAHASAN}

Deskripsi data dihitung ukuran pemusatan (tendensi sentral) dan penyebaran data (tendensi penyebaran). Selanjutnya data hasil penelitian disajikan dalam table distribusi frekuensi dan grafik histogram untuk setiap kelompok data (Tabel 1). 
Distribusi frekuensi skor kecerdasan emosional siswa (X) terlihat sebanyak 30 orang atau 34,89\% siswa memperoleh skor disekitar rata-rata, sebanyak 31 orang atau $36,04 \%$ siswa memperoleh skor diatas rata-rata dan sebanyak 25 orang atau $29,07 \%$ siswa memperoleh skor dibawah rata-rata (Tabel 2 dan Gambar 1).

Distribusi frekuensi Nilai Hasil Belajar Siswa (Y) sebanyak 20 orang atau $23,26 \%$ siswa memperoleh skor disekitar rata-rata, sebanyak 43 orang atau 50\% siswa memperoleh skor diatas rata-rata dan sebanyak 23 orang atau 26,74\% siswa memperoleh skor dibawah rerata (Tabel 3 dan Gambar 2).

Tabel 1. Rekapitulasi Hasil Perhitungan Statistik Deskriptif

SAMPEL

DATA STATISTIK

TENDENSI SENTRAL

TENDENSI

PENYEBARAN

\begin{tabular}{ccccccccccc} 
& $\mathrm{n}$ & $\Sigma$ & $\max$ & $\min$ & $\mathrm{r}$ & Mean & Me & Mo & $\mathrm{S}$ & $\mathrm{S}^{2}$ \\
\hline $\mathrm{X}$ & 86 & 15246 & 213 & 142 & 71 & 177,28 & 177 & 178 & 12,53 & 156,65 \\
$\mathrm{Y}$ & 86 & 6465 & 100 & 30 & 70 & 75,17 & 75,5 & 90 & 15,17 & 230,26 \\
\hline Keterangan & \multicolumn{1}{l}{$\mathrm{X}=$} & \multicolumn{1}{c}{ Skor Kecerdasan Emosional } \\
& \multicolumn{1}{c}{$\mathrm{Y}$ Nilai Hasil Belajar Siswa Kelas VII } & & & & &
\end{tabular}

Tabel 2. Distribusi Frekuensi Skor Kecerdasan Emosional (X)

\begin{tabular}{cccccc}
\hline Kelas Interval & $\begin{array}{c}\text { Nilai } \\
\text { Tengah }\end{array}$ & $\begin{array}{c}\text { Batas } \\
\text { Bawah }\end{array}$ & $\begin{array}{c}\text { Batas } \\
\text { Atas }\end{array}$ & $\begin{array}{c}\text { Frekuensi } \\
\text { Absolut }\end{array}$ & $\begin{array}{c}\text { Frekuensi } \\
\text { Relatif \% }\end{array}$ \\
\hline $141-150$ & 145,5 & 140,5 & 150,5 & 1 & 1.16 \\
$151-160$ & 155,5 & 150,5 & 160,5 & 6 & 6.98 \\
$161-170$ & 165,5 & 160,5 & 170,5 & 18 & 20.93 \\
$171-180$ & 175,5 & 170,5 & 180,5 & 30 & 34.89 \\
$181-190$ & 185,5 & 180,5 & 190,5 & 19 & 22.09 \\
$191-200$ & 195,5 & 190,5 & 200,5 & 9 & 10.47 \\
$201-210$ & 205,5 & 200,5 & 210,5 & 2 & 2.32 \\
$211-220$ & 215,5 & 210,5 & 220,5 & 1 & 1.16 \\
\hline & Jumlah & 86 & 100 \\
\hline
\end{tabular}

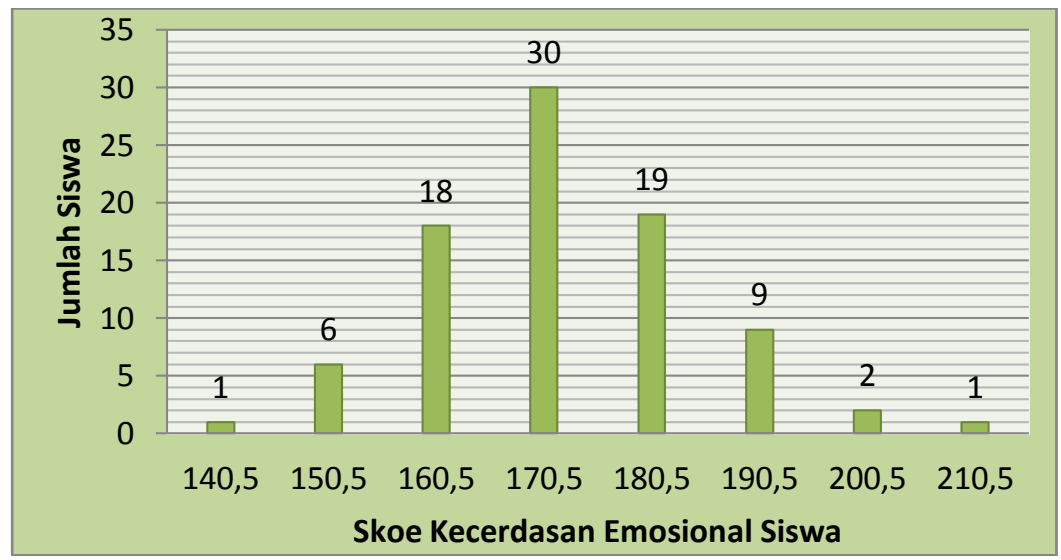

Gambar1. Skor Kecerdasan Emosional Siswa (X) 
Table 3. Distribusi Frekuensi Hasil Belajar Siswa (Y)

\begin{tabular}{cccccc}
\hline $\begin{array}{c}\text { Kelas } \\
\text { Interval }\end{array}$ & $\begin{array}{c}\text { Nilai } \\
\text { Tengah }\end{array}$ & $\begin{array}{c}\text { Batas } \\
\text { Bawah }\end{array}$ & Batas Atas & $\begin{array}{c}\text { Frekuensi } \\
\text { Absolut }\end{array}$ & $\begin{array}{c}\text { Frekuensi } \\
\text { Relatif \% }\end{array}$ \\
\hline $30-39$ & 34.5 & 29.5 & 39.5 & 1 & 1.16 \\
$40-49$ & 44.5 & 39.5 & 49.5 & 6 & 6.98 \\
$50-59$ & 54.5 & 49.5 & 59.5 & 6 & 6.98 \\
$60-69$ & 64.5 & 59.5 & 69.5 & 10 & 11.63 \\
$70-79$ & 74.5 & 69.5 & 79.5 & 20 & 23.26 \\
$80-89$ & 84.5 & 79.5 & 89.5 & 22 & 25.58 \\
$90-99$ & 75 & 89.5 & 100 & 21 & 24.42 \\
\hline \multicolumn{7}{c}{ Jumlah } & & $\mathbf{8 6}$ & $\mathbf{1 0 0}$ \\
\hline
\end{tabular}

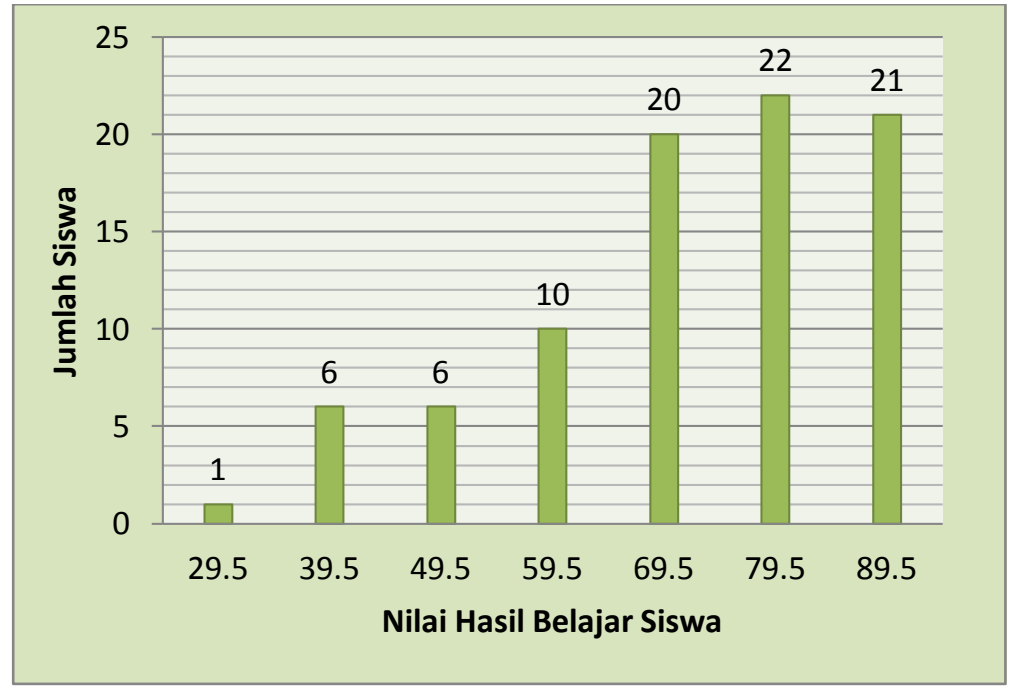

Gambar 2. Nilai Hasil Belajar Siswa (Y)

Uji validitas data, dari 50 pernyataan angket kecerdasan emosional semua pernyataan valid, dan dari 25 tes hasil belajar didapat 20 soal valid. Hasil uji reliabilitas pada skala kecerdasan emosional dan tes hasil belajar dihitung dengan menggunakan rumus Alpha Cronbach. Setelah dihitung, maka diperoleh nilai koefisien reliabilitas alpha sebesar 2.452 untuk kecerdasan emosional dan 0.762 nilai hasil belajar siswa. hal ini menunjukkan bahwa instrumen tes hasil belajar yang ada memiliki reliabilitas yang sangat baik sehingga memungkinkan atau layak digunakan dalam penelitian.

Pengujian uji normalitas dan uji homogenitas, termasuk uji linieritas regresi dan korelasi yang digunakan untuk mengambil suatu kesimpulan mengenai hubungan kedua variabel penelitian, yaitu kecerdasan emisonal (X) dan hasil belajar siswa (Y). Pengujian uji normalitas menggunakan uji Liliefors pada taraf signifikansi $(\alpha=0,05)$. Hasil perhitungan normalitas kelompok data nilai hasil belajar siswa (Y) atas dasar skor 
kecerdasan emosional siswa (X) menggunakan uji Liliefors diperoleh nilai $\mathrm{L}_{\mathrm{hitung}}$ (Lo) sebesar 0.0914 Dari hasil perhitungan terlihat bahwa nilai $\mathrm{L}_{\text {hitung }}(0.0914)$ lebih kecil dari nilai $\mathrm{L}_{\text {tabel }}(0,05 ; 86)(0.0955)$. pengujian menerima hipótesis nol (Ho) berarti kelompok data nilai hasil belajar siswa (Y) dengan skor kecerdasan emosional (X) berdistribusi normal.

Hasil pengujian homogenitas menggunakan uji Bartlett pada taraf signifikansi ( $\alpha$ $=0,05)$. Untuk jumlah kelompok data (k) sebanyak 41 data, yaitu 43.773 dan sebaliknya, menolak hipótesis nol (Ho) bahwa data memiliki variansi yang tidak homogen jika harga $x{ }^{2}{ }_{\text {hitung }}$ ( Lo) lebih besar dari $x{ }^{2}$ tabel. Perhitungan uji homogenitas dengan mengelompokkan data hasil belajar siswa (Y) berdasarkan kesamaan data skor kecerdasan emosional siswa (X) untuk memperoleh derajat kebebasan data (dk) dan menghitung variansi gabungan kedua kelompok data yang digunakan untuk mencari nilai $x{ }^{2}{ }_{\text {hitung. }}$. Dari hasil perhitungan diperoleh nilai $x^{2}$ hitung sebesar (42.173). Pengujian menerima hipótesis nol (Ho) berarti variansi kelompok data nilai hasil belajar siswa (Y) atas data skor kecerdasan emosional berasal dari data yang homogen. Hasil pengujian menunjukkan bahwa prasyarat normalitas data untuk pengujian hipótesis terpenuhi. Dengan terpenuhinya kedua prasyarat análisis data, maka penelitian dapat dilanjutkan untuk menguji hipótesis penelitian yang diajukan.

Pengujian hipotesis, hasil perhitungan regresi sederhana hubungan antara kecerdasan emosional dengan hasil belajar siswa (Y) menggunakan análisis regresi linear sederhana, diperoleh harga konstanta a sebesar 282.6 dan harga b sebesar -1.17. Berdasarkan harga-harga a dan b tersebut maka diperoleh persamaan regresi linear sederhana $\hat{Y}=282.6-1.17 \mathrm{X}$. Selanjutnya dilakukan uji signifikasi linearitas regresi menggunakan teknik Analisis Varians (Anava) untuk menguji kekuatan hubungan antara variabel bebas kecerdasan emosional (X) terhadap variabel terikat hasil belajar siswa (Y). (tabel 4 dan grafik 3).

Dari hasil perhitungan pada tabel Analisis Varians (Anava) diperoleh nilai Fhitung sebesar 1097.79 lebih kecil dari $F_{\text {tabel }}(\alpha=0.05)$ sebesar 1.35 (F $\left.F_{\text {hitung }}>F_{\text {tabel }}\right)$ Berarti hasil pengujian menunjukkan bahwa regresi antara variabel bebas kecerdasan emosional siswa $(\mathrm{X})$ dengan variabel terikat nilai hasil belajar $(\mathrm{Y})$ adalah signifikansi. Sedangkan untuk uji linearitas regresi diperoleh nilai Fhitung sebesar 1.10 lebih kecil dari $F_{\text {tabel }}(a=0.05)$ sebesar 4.96. Berarti hasil pengujian menunjukkan bahwa hubungan antara variabel bebas kecerdasan emosional siswa $(\mathrm{X})$ dengan variabel terikat nilai hasil belajar (Y) memiliki regresi yang linear. Berdasarkan grafik 3 tergambarkan bahwa 
garis regresi $\hat{\mathrm{Y}}=282.6-1.17 \mathrm{X}$ terlihat bahwa hubungan antara kecerdasan emosional siswa (X) dengan hasil belajar siswa (Y) bersifat hubungan negatif. Hal ini menunjukkan bahwa setiap satu skor kecerdasan emosional siswa (X) meneyebabkan penurunan nilai hasil belajar (Y) sebesar 1.17 pada konstanta 282.6.

Tabel 4. Tabel Anava Regresi Linear Sederhana

\begin{tabular}{cccccc}
\hline Sumber Variansi & $\mathbf{d b}$ & $\mathbf{J K}$ & $\mathbf{R J K}$ & $\mathbf{F}_{\text {hitung }}$ & $\mathbf{F}_{\text {tabel }} \alpha=\mathbf{0 . 0 5}$ \\
\hline Total & 86 & 505575 & & & \\
Regresi a & 1 & 486002.62 & 486002.62 & & \\
Regresi b & 1 & 18180.85 & 18180.85 & 1097.21 & 1.82 \\
Sisa & 84 & 1391.53 & 16.57 & & \\
Tuna Cocok & 39 & 932308.52 & 23905.35 & 1.15 & 4.54 \\
Galat & 41 & 933700 & 20748.89 & & \\
\hline
\end{tabular}

Keterangan : JK : Jumlah Kuadrat RJK : Rata-Rata Jumlah Kuadrat $\mathrm{dk} \quad$ : Derajat kebebasan

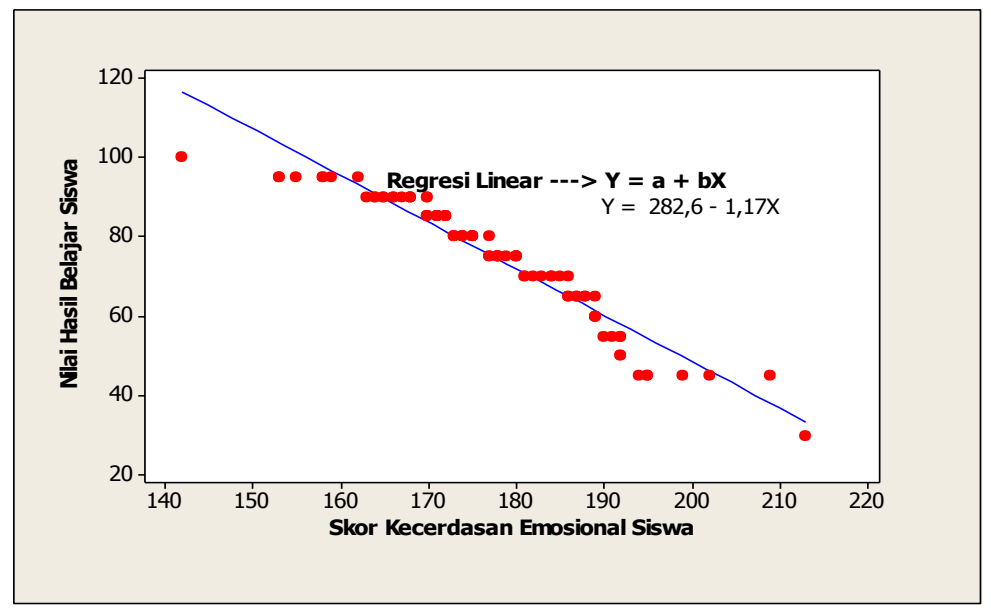

Gambar 3. Hubungan Kecerdasan Emosional Siswa (X) Dengan Hasil Belajar Siswa (Y) Melalui Grafik Garis Regresi $(\hat{Y}=\hat{Y}=282.6-1.17 X)$

Pengujian koefisien korelasi sederhana diperoleh bahwa nilai koefisien korelasi (r) sebesar $0.963(96,3 \%)$ dan koefisien determinasi $\left(\mathrm{R}^{2}\right)$ sebesar 0.927 atau $92,7 \%$. Hasil uji signifikan koefisien korelasi dengan menggunakan ujji t pada taraf signifikansi ( $1-\alpha=0.05)$ untuk derajat kebebasan $(\mathrm{dk}=\mathrm{n}-2)$ dengan jumlah sampel (n) sebanyak 86 siswa menunjukkan bahwa $t_{\text {hitung }}$ (32.69) lebih kecil $(<)$ dari $t_{\text {tabel }}(0.95 ; 84) 1.671$, berarti pengujian tolak hipotesis (Ho) berarti bahwa koefisien kolerasi signifikan (Tabel $5)$. 
Tabel 5. Rekapitulasi Uji Koefisien Korelasi Sederhana Menggunakan Uji t pada taraf $\alpha=0.05$.

\begin{tabular}{ccccccc}
\hline $\begin{array}{c}\text { Jumlah } \\
\text { Sampel (n) }\end{array}$ & $\begin{array}{c}\text { Koefisien } \\
\text { Korelasi }(\mathrm{r})\end{array}$ & $\begin{array}{c}\text { Koefisien } \\
\text { Determinan }\left(\mathrm{r}^{2}\right)\end{array}$ & $\mathrm{t}_{\text {hitung }}$ & Tanda & $\mathrm{t}_{\text {tabel }}$ & Hasil \\
\hline 86 & 0.963 & 0.927 & 32.69 & $>$ & 1.671 & $\begin{array}{c}\text { Korelasi } \\
\text { Signifikan }\end{array}$ \\
\hline
\end{tabular}

Hasil pengujian ini menunjukkan bahwa hipótesis penelitian yang diajukan, yaitu terdapat hubungan antara kecerdasan emosional siswa $(\mathrm{X})$ dengan hasil belajar siswa (Y) dalam penelitian ini. Dengan demikian hasil penelitian dapat disimpulkan bahwa terdapat hubungan yang signifikan antara kecerdasan emosional siswa (X) dengan hasil belajar siswa (Y). Semakin tinggi skor kecerdasan emosional siswa maka semakin tinggi nilai hasil belajar siswa dengan kekuatan hubungan variabel sebesar 0.963. Hubungan antara variabel yang signifikan ini didukung koefisien determinasi $\left(\mathrm{R}^{2}\right)$ sebesar 0.927 . Hal itu berarti bahwa $92.7 \%$ variasi yang terjadi pada hasil belajar siswa ditentukan oleh kecerdasan emosional dalam persamaan regeresi $\hat{\mathrm{Y}}=282.6-$ $1.17 \mathrm{X}$.

Dalam taxtonomy of educational objectives, Bloom, dkk (1971) dalam Silverius (2001) mengklasifikasikan hasil belajar menjadi tiga ranah, yaitu kognitif, ranah afektif dan ranah psikomotorik. Menurut Bloom (1971), segala upaya yang menyangkut aktivitas otak adalah yang termasuk dalam ranah kognitif. Dalam ranah kognitif, hasil belajar tersusun dalam enam tingkatan. Enam tingkatan tersebut ialah, (1) Pengetahuan atau ingatan (knowledge), (2) Pemahaman (comprehension), (3) Penerapan (application), (4) Analisis (analysis), (5) Sintesis (synthesis), dan (6) Penilaian/penghargaan/evaluasi (evaluation). Kedua aspek pertama disebut kognitif tingkat rendah dan keempat aspek berikutnya termasuk kognitif tingkat tinggi. Menurut Haris dan Jihad (2009), ranah psikomotorik terdiri dari 5 (lima) tingkatan yaitu, 1) Peniruan (menirukan gerak), 2) Penggunaan (menggunakan konsep untuk melakukan gerak), 3) Ketepatan (melakukan gerak dengan benar), 4) Perangkaian (melakukan beberapa gerakan sekaligus dengan benar), 5) Naturalisasi (melakukan gerak secara wajar). Sedangkan ranah afektif terdiri dari lima tingkatan yaitu, 1) Pengenalan (ingin menerima, sadar akan adanya sesuatu), 2) Merespon (aktif berpartisipasi), 3) Penghargaan (menerima nilai-nilai, setia pada nilai-nilai tertentu), 4) Pengorganisasian 
(menghubung-hubungkan nilai-nilai yang dipercaya) dan 5) Pengamalan (menjadikan nilai-nilai sebagai bagian dari pola hidup). Ditambahkan Bloom (1971), Ranah afektif berkenaan dengan sikap yang terdiri dari 5 (lima) aspek, yakni penerimaan, jawaban atau reaksi, penilaian, organisasi, dan internalisasi. Ranah psikomotoris berkenaan hubungannya dengan hasil belajar ketrampilan dan kemampuan bertindak. Ada 6 (enam) aspek ranah psikomotoris, yaitu : 1) Gerakan refleks; 2) Keterampilan gerakan dasar; 3) Kemampuan perceptual; 4) Keharmonisan atau ketepatan; 4) Gerakan ketrampilan kompleks; 5) gerakan ekspresif; dan 6) interpretatif.

Ketiga ranah tersebut menjadi objek penilaian hasil belajar. Diantara ketiga ranah itu, ranah kognitiflah yang paling banyak dinilai oleh para guru disekolah, karena berkaitan dengan kemampuan para siswa dalam menguasai isi bahan pelajaran. Menurut Sudjana (1989), hasil belajar yang dicapai siswa dipengaruhi oleh dua faktor yakni faktor dari dalam diri siswa dan faktor dari luar diri siswa. Dari pendapat ini faktor yang dimaksud adalah faktor dalam diri siswa perubahan kemampuan yang dimilikinya seperti yang dikemukakan oleh Clark (1981) dalam Sudjana (1989), menyatakan bahwa hasil belajar siswa disekolah $70 \%$ dipengaruhi oleh kemampuan siswa dan $30 \%$ dipengaruhi oleh lingkungan. Demikian juga faktor dari luar diri siswa yakni lingkungan yang paling dominan berupa kualitas pembelajaran. Kualitas pengajaran yang dimaksud adalah profesional yang dimiliki oleh guru. Artinya kemampuan dasar guru baik di bidang kognitif (intelektual), bidang sikap (afektif) dan bidang perilaku (psikomotorik).

Secara umum uraian di atas disimpulkan bahwa kecerdasan emosional merupakan salah satu faktor yang penting yang seharusnya dimiliki oleh siswa yang memiliki kebutuhan untuk meningkatkan hasil belajar yang lebih baik di sekolah. Hubungan keterkaitan antara kecerdasan emosional dengan hasil belajar adalah bentuk postulat dari keberhasilan di sekolah serta bukan diramalkan oleh kumpulan fakta seorang siswa atau kemampuan dininya untuk membaca, melainkan oleh ukuran-ukuran emosional dan sosial, yakni eksistensi diri sendiri dan mempunyai minat; tahu pola perilaku yang diharapkan orang lain dan bagaimana mengendalikan dorongan hati untuk berbuat tidak nakal; mampu menunggu, mengikuti petunjuk dan mengacu pada guru untuk mencari bantuan; serta mengungkapkan kebutuhan-kebutuhan saat bergaul dengan siswa lain. Dengan demikian bahwa kecerdasan emosional merupakan salah 
satu faktor yang penting yang seharusnya dimiliki oleh siswa yang memiliki kebutuhan untuk meningkatkan hasil belajar yang lebih baik di sekolah. Pada tataran hipotesis statistik berarti menolak hipotesis nol (Ho) dan menerima hipotesis Alternatif (Hi) yang mengungkapkan bahwa ada hubungan antara kecerdasan emosional dengan hasil belajar secara signifikan.

\section{KESIMPULAN}

Berdasarkan hasil dan pembahasan analisis deskriptif dan pengujian hipotesis dapat diberikan beberapa kesimpulan, yaitu :

1. Terbukti nyata ada hubungan antara kecerdasan emosional dengan hasil belajar siswa SMPN 21 Batam (F hitung 1097,79 > F table $\alpha$ 5\% 1,82).

2. Hasil pengujian regresi linear sederhana dengan persamaan $\hat{Y}=282.6-1.17 \mathrm{X}$, yang berarti bahwa regresi antara variabel bebas kecerdasan emosional siswa (X) dengan variabel terikat nilai hasil belajar (Y) adalah linier dan signifikansi. Berarti setiap kenaikan satu skor kecerdasan emosional siswa (X) meneyebabkan peningkatan nilai hasil belajar (Y) sebesar 1,17 pada konstanta 282,6.

3. Pengujian korelasi product moment menunjukkan korelasi (r) sebesar 0,963 dan koefisien determinasi $\left(\mathrm{R}^{2}\right)$ sebesar 0,927. Untuk selanjutnya dilakukan uji signifikansi koefisien kolerasi menggunakan Uji t terlihat bahwa $t_{\text {hitung }}(32.69)>$ dari $\mathrm{t}_{\text {tabel }}(0.95 ; 84)$ 1.671. Artinya hasil pengujian menolak hipotesis nol (Ho).

\section{REFERENSI}

Aunnurrahman, 2009. Belajar dan Pembelajaran. Alfabeta, Bandung.

Bloom, B. 1971. Toxonomy of Educational Objectives, Cognitive Domain. David McKay Co, New York.

Goleman, D., 2002. Emitional Intelligence (terjemahan). PT Gramedia Pustaka Utama, Jakata.

2000. Emitional Intelligence (terjemahan). PT Gramedia Pustaka Utama, Jakata.

Muhammad, A., 2004. Guru Dalam Proses Belajar Mengajar. Sinar Baru. Bandung.

Salovey, 1990. Emotional Intelligence pada Anak. Gramedia, Jakarta. 
Sugiyono, 2011. Statistika Untuk Penelitian, IKAPI, Bandung.

Sudjana, N., 2009. Penilaian Hasil Proses Belajar Mengajar, PT. Remaja Rosdikarya, Bandung.

Soeparno. W., 2008. Peningkatan Hasil Belajar Siswa. Pustaka Setia, Jakarta.

Suyono, 2009. Hasil Belajar Siswa. Gramedia, Jakarta. 